I thank Dr. Roy Gigg for his help and advice. Patricta M. Carroll

Biochemistry Department,

Institute of Orthopædics

(British Postgraduate Medical Federation), Stanmore, Middlesex.

' Strange, R. F., and Kent, L. H., Biochem. J., 71, 333 (1959).

${ }^{2}$ Gigg, R., and Carroll, P. M., Nature, 191, 495 (1961).

"Kuhn, R., and Baer, H. H., Chem. Ber., 86, 724 (1953).

"Avison, A. W. D., J. Chem. Soc., 735 (1955).

${ }^{3}$ Lambert, R., and Zilliken, F., Chem. Ber., 93, 2915 (1960)

'Nefkens, G. H. L, and Tesser, G. I., J. Amer. Chem. Soc., 83, 1263 (1961)

'Orndorif, w. R., and Pratt, D. S., Amer. Chem. J., 47, 89 (1912).

\section{Combination Analysis of Rabbit Serum Proteins, using High-resolution Porath Zone Electrophoresis and Starch-gel Electrophoresis}

Two-dimensional electrophoresis by the method of Poulik and Smithies ${ }^{1}$ provides a powerful tool for the identification of serum protein bands separated in uni. dimensional starch-gel electrophoresis. It has in some, easos revealed the presence of unsuspected components which are masked by others in tho unidimensional run $^{2}$. The mothod is, however, severely limited by small loading of protein sample possible by means of filter-paper insertion. Some improvoment may be gained by making the preliminary run in agar where not only is tho loading higher but also the resolution is more powerful than on paper. Thus two $\alpha_{1}$ and two $\alpha_{2}$ components are to bo distinguished in agar runs of rabbit serum ${ }^{3}$.

In order to start the starch-gol eloctrophoresis of the second phase of a two-dimensional analysis with an adequate loading of protein, it was decided to concentrate fractions from a Porath zone electrophoresis experimont. Protein concentrations were brought back to 1 per cent or somewhat more, with the exception of the fraetions from the small $\gamma_{2}$ peaks.

The analysis obtained by this combination of methods is presented in qualitative form in Figs. 1 and 2. It is immediately apparent that there exists a much groator complexity of serum protein compononts than has previously been recognizod. Albumin has been run off tho Porath column and is not retained in tho analysis. Four $\alpha$ components are recognized in the Porath scan, and throo of these, $\alpha_{1 a}, \alpha_{1 b}$ and $\alpha_{2}$, have been concentrated and run on starch. $\alpha_{2} b$ appears to be resolved scarcely from tho $\beta_{1}$, yet the gel analysis shows a marked difference of composition between even these two closely adjacent fractions. Little slow $\alpha_{2} b$ macroglobulin, for example, is present in the $\beta_{1}$, and the heavily staining major $\beta_{3}$ component is only slightly represented in tho $\alpha_{2} b$.

Perhaps the most interesting finding lies in the demonstration that the leading slow $\alpha$ band is an $\alpha_{1} b$ and to a lossor extent an $\alpha_{1 a}$ component. Here is a first example of an $\alpha_{1}$ slow component, possibly macroglobulin, normally present in rabbit sera in our experionec, though apparontly not demonstrated by tho older horizontal starch-gel technique. A component similar to the

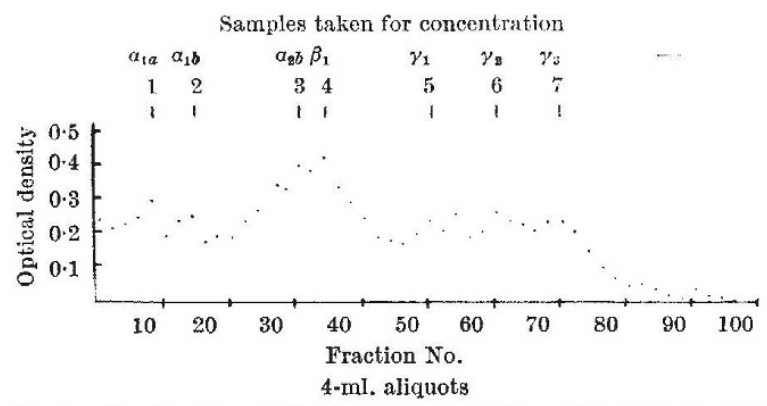

Fig. 1. Combination analysis of normal rabbit serum protein. First phase, Porath column clectrophoresis showing fractions cut for recon- slow $\alpha_{2}$ has been domonstrated to appear druing pregnancy and certain tumour-boaring conditions in the rat ${ }^{4}$. We are investigating the presence of this component in other species.

A further point of interest is that the $\gamma_{1}$ (or $\beta_{2}$ ) fraction gives a single rather diffuse zone which has in fact greater mobility than the slow $\alpha_{1}$ and thus lies ahead of it in the unidimensional pattorn. Most accounts in the literature fail to mention the presence of $\gamma$ material so far ahead of the well. The resolution of the $\gamma$-globulins would thus appear to be mueh greater on starch than is generally supposed, although they do not form sharp bands. It is open to question whether this $\gamma_{1}$ zone ineludes the $\gamma_{3}$ macroglobulin, and work is in progross to investigate this point.

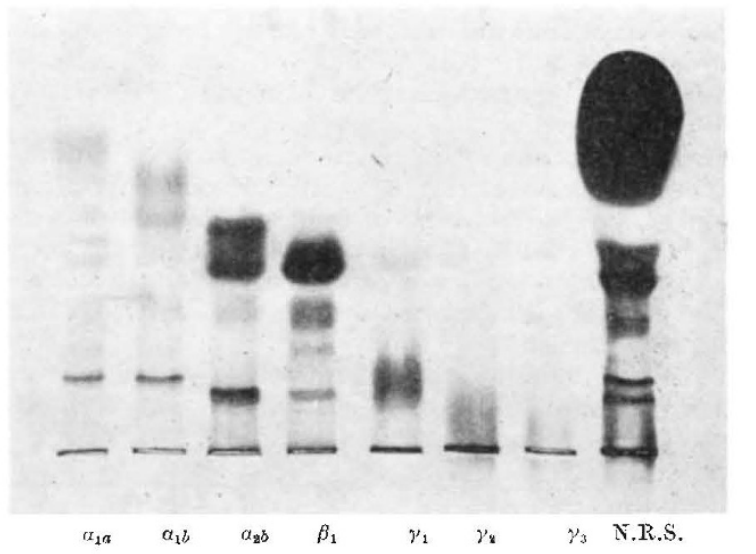

Fix, 2 . Second phase. Vertical stareh-gel electroploresis of the series if eoncentrates gerived from Fig. 1. N.R.... Normal rabbit serum

The total number of components recounized as distinct by visual inspection of the original gel, and not shared by adjacont fractions, we rocord as 25 in this analysis. This compares with tho previous 10-11 distinguished in this specios by unidimensional starch-gol electrophorosis. Since several of tho major zones, such as $f \alpha_{1} a, f \alpha_{1, b}$ and $\gamma_{1}$. are diffuse, it may be that further refinements of technique will lead to sub-fractionation of some of these also. No attempts have yet been made to vary buffor conditions from those establishod by Smithies.

Zone electrophoresis was carried out by Porath's method ${ }^{\bar{s}}$ on a column kept at about $5^{\circ} \mathrm{C}$, of dimensions $90 \mathrm{~cm}$ long and $2.5 \mathrm{~cm}$ diamotor, on Munlstell propared collulose, using veronal buffor $p \mathbf{H} 8.5, i=0.05$.

The run was for $120 \mathrm{~h}$ at $1,000 \mathrm{~V}, 20 \mathrm{~m}$.amp.: olution set at a flow-rate of about $16 \mathrm{ml} / \mathrm{h}$. Aliquots of approximately $4 \mathrm{ml}$. were collocted on a time-controlled 'Beaumaris' fraction colloctor working overnight. Albumin was run off the column, being collected in a dialysis sack tiod over the outlot. Protein determinations were made on alternate samples, using the method of Lowry et al. ${ }^{6}$. Starch-gol electrophoresis was carried out by the vertical method of Smithios ${ }^{7}$ using his buffer solutions.

\section{W. A. Hemmines \\ R. E. Jones}

Agricultural Research Council Unit of Exnbryology, Department of Zoology,

Univorsity College of North Wales, Bangor.

${ }^{1}$ Poulik, M. D., and Smithies, O., Biochem. J., 68, 636 (1958).

2 Beaton, G. II., Selby, A. E., and Wright, A. M., J. Biol. (Yhem., 236, 2001 (1961).

${ }^{3}$ Pierce, A. E., Biochim. Biophys. Acta, 59, 149 (1962).

¿Beaton, G. H., Selby, A. E., Veen, M. J., and Wright A. M., J. Biol. Chem. 236, 2005 (1961).

${ }^{5}$ Porath, J., Biochim. Biophys. Acta, 22, 151 (1956).

'Lowry, O. H., Rosebrough, N. J., Farr, A. L., and Randall, K. J., J. Biol. Chem., 193, 265 (1951).

; Smithies, 0., Biochem. J., "71, 585 (1959) 